\title{
Femtosecond assisted intrastromal corneal ring (ISCR) implantation for the treatment of corneal ectasia
}

\author{
Avaliação dos resultados do implante do anel intraestromal com laser de femtosegundo no \\ tratamento de ectasias corneanas
}

Cristina Cardoso Coimbra ${ }^{1}$, Marcos Tonelli Gomes ${ }^{1}$, Mauro Campos $^{1}$, Edvaldo Soter de Figueiroa Junior ${ }^{1}$, Eduardo Parente Barbosa ${ }^{1}$, Myrna Serapião dos Santos ${ }^{2}$

\section{ABSTRACT \\ Purpose: To assess the outcomes of intrastromal corneal ring (ISCR) implantation for the treatment of corneal ectasia.}

Methods: Thirty-five consecutive patients with secondary corneal ectasia treated with keraring intrastromal corneal ring segment implantation aided by intralaser femtosecond technique (K-ICRS-FS) were evaluated. Visual acuity (logMAR), refraction and astigmatism vector analysis were measured preoperatively and 3 months postoperatively using vector analysis as described by some authors

Results: Visual acuity improved from $0.40 \pm 0.20$ to $0.25 \pm 0.13 \log M A R(p=0.0002)$, with reduction of the spherical equivalent from $-5.41 \pm 4.78 \mathrm{D}$ to $-2.83 \pm 3.29 \mathrm{D}$ $(\mathrm{P}=0.0002)$. Mean astigmatism reduction was $3.92 \pm 2.52 \mathrm{D} . \mathrm{K}$ maximum decreased from $51.65 \pm 5.83 \mathrm{D}$ preoperatively to $48.58 \pm 5.54 \mathrm{D}(\mathrm{p}=0.001) 3$ months after the surgery and K minimum decreased from 45.92 $\pm 4.64 \mathrm{D}$ to $43.96 \pm 5.06 \mathrm{D}(\mathrm{p}=0.0041)$. There were no intraoperative or postoperative complications.

Conclusion: Intrastromal corneal ring implantation with the use of a femtosecond laser was a safe procedure, with low risk of complications and significant improvement on visual acuity and topographic data in this seeting of patients with secondary corneal ectasia.

Keywords: Corneal topography; Cornea/pathology; Astigmatism/physiopathology; Keratoconus/physiopathology; Keratoconus/surgery; Lasers, excimer/therapeutic use; Prosthesis implantantion; Refraction, ocular; Visual acuity

\section{RESUMO}

Objetivo: Avaliar os resultados do implante de anel intraestromal (Keraring ${ }^{\circledR}$ ) com laser de femtosegundo para o tratamento de ectasias corneanas (ceratocone e degeneração marginal pelúcida).

Método: Estudo retrospectivo em 35 pacientes consecutivos com ectasia corneana submetidos a implante de anel intracorneano (Keraring ${ }^{\circledR}$ ). Acuidade visual (logMAR), refração, ceratometria e a análise vetorial do astigmatismo foram as variáveis analisadas. O túnel para o implante dos segmentos foiconfeccionado com laser defemtosegundo. Os pacientes foram seguidos pelo período mínimo de três meses.

Resultados: A acuidade visual corrigida melhorou de 0,40 $\pm 0,20$ para 0,25 $\pm 0,13$ $(p=0,0002)$, com diminuição do equivalente esférico de $-5,41 \pm 4,78 \mathrm{D}$ no pré-op. para $-2,83 \pm 3,29$ D no pós-op. ( $p=0,0002)$ e média de 3,92 $\pm 2,52$ D na análise vetorial do astigmatismo. O K máximo variou de 51,65 $\pm 5,83 \mathrm{D}$ para 48,58 $\pm 5,54 \mathrm{D}(p=0,000)$ e o K mínimo de 45,92 $\pm 4,64 \mathrm{D}$ para 43,96 $\pm 5,06 \mathrm{D}$ ( $p=0,0041)$. Não houveram complicações intra ou pós-operatórias).

Conclusão: Os resultados desteestudo mostraram queo implante do anel intra estromalé umprocedimento seguro, combaixo risco de complicações, tendo determinado importante melhora na acuidadevisuale dos dados topográficos depacientes comectasias corneanas.

Descritores: Topografia da córnea; Córnea/patologia; Astigmatismo/fisiopatologia Ceratocone/fisiopatologia: Ceratocone/cirurgia: Lasers de excimer/uso terapêutico: Implante de prótese; Refração ocular; Acuidade visual

\section{INTRODUCTION}

Corneal ectasia is a bilateral, asymmetric, and progressive disease that causes corneal thinning and increase of the corneal curvature ${ }^{(1)}$, inducing myopia and irregular astigmatism, and leading to progressive visual acuity decrease.

The most prevalent cause of ectasia is the keratoconus and the pellucid marginal degeneration. Keratoconus is characterized by corneal thinning and progressive increase of the corneal curvature, stromal thinning and irregular astigmatism ${ }^{(2)}$, while pellucid marginal degeneration is characterized by inferior stromal thinning extending from 4 to 8 hours in a crescent shape ${ }^{(3)}$.

The correction with spectacles provides good visual acuity in the early phases of the disease, while there is no important irregular astigmatism. In advanced cases, the use of rigid contact lenses is ne- cessary to restore vision. With the progression of the ectasia, and low best corrected visual acuity despite the use of spectacles or contact lenses and/or intolerance to contact lens, the corneal transplant is indicated ${ }^{(4,5)}$

Since the 40's, efforts have been made by several investigators to keep corneal ectasia stable with the purpose of postpone or avoid the corneal transplant. The intracorneal ring segment implants (ICRS) were idelized by Joaquim Barraquer in the 50's with the aim of molding the corneal curvature producing stability to refractive procedures(6)

The ICRS implant acts inducing a significant corneal steepening followed by an adjacent corneal flattening that reduces the corneal power and might improve the visual acuity with or without correction. The main advantages of this procedure are: safety, reversibility and stability ${ }^{(7)}$.
Submitted for publication: January 9, 2012

Accepted for publication: March 6, 2012

Study carried out at Cornea Service, Hospital de Olhos Paulista, São Paulo (SP) - Brazil.

Physician, Hospital de Olhos Paulista, São Paulo (SP), Brazil.

Physician, Cornea and External Diseases Service, Hospital de Olhos Paulista, São Paulo (SP) Brazil.
Funding: No specific financial support was available for this study.

Disclosure of potential conflicts of interest: C.C.Coimbra, None; M.T.Gomes, None; M.Campos, None; E.S.Figueiroa Jr, None; E.P.Barbosa, None; M.S.Santos, None.

Correspondence address: Cristina Cardoso Coimbra. Alameda dos Aicás, 1404 - Apto. 73 - São Paulo (SP) - 04086-002 - Brazil - E-mail: tina_coimbra@yahoo.com.br

Aprovação pelo comitê de ética e pesquisa: Aprovado pelo Comitê de Ética do Instituto Verter CAAE $00030389000-08$ 
Keraring ${ }^{\circledR}$ intrastromal implant (ISCR) (Mediphacos - Belo Horizonte), differs from available commercial options because it was especially designed for the treatment of corneal ectasia. It is positioned close to the pupillary axis producing a surface regularization and refraction correction. It is characterized by having a triangle transversal section which supposedly reduces glare complaints. It dimensions are $0.6 \mathrm{~mm}$ (bottom surface), arch segments from 90 to 210 degrees, variable thickness from 0.15 to $0.30 \mathrm{~mm}$, inner diameter from 5.0 or $6.0 \mathrm{~mm}^{(8)}$ and 5.6 or 7.0 (external diameter, of 5.0 and 6.0 respectively).

ICRS implant complications include extrusion, migration and superficialization of the implanted segments, besides the possible progression of the ectasic disease. Many of these complications can be reduced and even eradicated by the use of a femtosecond laser to make the tunnel instead of the manual technique ${ }^{(2)}$.

The femtosecond laser acts through the photodisruption mechanism promoting a tissue dissection by forming carbon dioxide microbubbles and water vapor in a chosen depth. It has the benefit to create a tunnel with uniform and precise depth of 360 degrees, being therefore, safer and liable to less intraoperative complications than the manual technique ${ }^{(2,8,9)}$.

\section{PURPOSE}

To assess the refractive outcomes of intrastromal ring (ISCR) implanted with femtosecond laser for the treatment of secondary corneal ectasia.

\section{METHODS}

This is a retrospective Clinical Study, approved by the Investigational Review Board - Ethics Committee of Verter Institute-CERPO (CAAE 00030389 000-08). The study protocol adhered to the tenets of the Declaration of Helsinki. All patients included in this study were informed about the procedure: surgical technique, possible risks and complications and treatment alternatives.

Before the surgery, the patients that agreed to participate signed an informed consent form included in the study protocol and received a copy of it.

\section{Patients selection}

The data was obtained from the patients records at Hospital de Olhos Paulista - in the city of São Paulo from the period of January, 2009 to July, 2010.

The sample includes 35 eyes from 35 patients with corneal ectasia (keratoconus or pellucid marginal degeneration) that underwent ISCR implantation surgery with femtosecond laser.

\section{INCLUSION CRITERIA}

Patients with keratoconus grade I to IV or pellucid marginal degeneration with at least one of those features: best corrected visual acuity $\geq$ count fingers and $\leq 20 / 30$; and/or total intolerance to the use of contact lens (hard and soft); and/or previous indication of corneal transplant, central pachymetry $\geq 400 \mu \mathrm{m}$ (ultrasonic or optical methods - Orbscan);

\section{EXCLUSION CRITERIA}

Previous ocular surgeries; monocular status; corneal curvature > 65 D; severe corneal opacity and significant corneal healing in the pupillary region, ruptures in the Descement's membrane (severe or healed hydropsy); other previous ocular diseases which can change the visual acuity or contraindicate the surgery such as herpetic ocular disease, dry eye, uncontrolled ocular atopic disease, cataracts, uveitis, indocyclitis, rubeosis iridis, glaucoma, previous retinal detachment, and retinal diseases with vascular change signs; systemic conditions such as Down's Syndrome, pregnancy, and chemical dependency; patients who did not have a proper postoperative follow-up, not attending the visits or who did not perform the requested exams.

\begin{tabular}{|c|c|}
\hline Stages & Characteristics \\
\hline । & $\begin{array}{l}\text { - Eccentric corneal curvature } \\
\text { - Myopia and/or induced astigmatism } \leq 5.0 \mathrm{D} \\
\text { - Corneal curvature } \leq 48.0 \mathrm{D} \\
\text { - Vogt's striae, no scars }\end{array}$ \\
\hline$\|$ & $\begin{array}{l}\text { - Myopia and/or induced astigmatism between } 5.0 \text { and } 8.0 \text { D } \\
\text { - Curvature } \leq 53.0 \mathrm{D} \\
\text { - Absence of central healings } \\
\text { - Pachymetry } \geq 400 \mu \mathrm{m}\end{array}$ \\
\hline III & $\begin{array}{l}\text { - Myopia and/or induced astigmatism between } 8.0 \text { and } 10.0 \text { D } \\
\text { - Curvature }>53.0 \text { D } \\
\text { - Absence of central healings } \\
\text { - Pachymetry from } 200 \text { to } 400 \mu \mathrm{m}\end{array}$ \\
\hline IV & $\begin{array}{l}\text { - Non measurable refraction } \\
\text { - Curvature }>55.0 \text { D } \\
\text { - Central healings, perforation } \\
\text { - Pachymetry } \geq 200 \mu \mathrm{m}\end{array}$ \\
\hline
\end{tabular}

\section{Preoperative assessment}

The preoperative (preop) assessment was performed in both eyes and included a review of clinical and ophthalmologic history and a series of ocular exams (contact lenses users were requested to interrupt its use for at least two weeks before the exams): distance visual acuity (DVA) assessment (AV) with the room lights on, using standard visual acuity tables (Snellen and logMAR); objective and subjective refractions in photopic conditions; slit lamp biomicroscopy; applanation tonometry with Goldmann applanation tonometer (Haag-Streit, Berna, Suiza) connected to the slit lamp; ultrasonic pachymetry with Humphrey pachymeter and pachymetric maps of the Orbscan II device (Bausch \& Lomb ${ }^{\circledR}$, Rochester, New York, USA); anterior chamber depth was measured with the Orbscan II device (Bausch \& Lomb ${ }^{\circledR}$, Rochester, New York, USA); indirect ophthalmoscopy, (Topcon Corporation, Tokyo, Japan) and 20 D lenses (Volk Optical Inc., Ohio, EUA).

\section{SURGical PROCEDURE}

The intrastromal ring implant surgery was performed by two surgeons (MSS and MTG) using the same surgical technique.

Nomograms provided by the manufacturer were used to choose the segment(s), based on the refraction, and topographic and pachymetric data of the patients.

\section{SURGiCAL TECHNIQUE}

Topical anesthesia with $0.5 \%$ proximetacaine; asepsis and antisepsis with 10\% povidone-iodine, and blepharostat positioning; $3 \%$ povidone-iodine solution for conjuctival sac antisepsis; identification of the corneal optic center with a pen based on the corneal reflex of the surgical microscope coaxial light, asking the patient to fix the center of its filament; the patient was positioned under the laser and the suction ring of the femtosecond laser was centered in his/her eye and the suction applied; the applanation cone was then connected to this set; the applanation cone was centered flattening the cornea and the laser was deactivated forming a tunnel of 360 degrees according to the depth chosen (70\% of the thickness of the thinner point in the 5-6 $\mathrm{mm}$ area, ring implant place) and with the incision in the corneal topographic axis of greatest curvature. The tunnel was programmed with the following parameters: Inner diameter: 5.00 mm; Outer diameter: $5.90 \mathrm{~mm}$; Incision length: $1.10 \mathrm{~mm}$; Incision thickness: $1.00 \mathrm{~mm}$; Power: $1.5 \mathrm{~J}$; Spot line separation: 4/4. 
Under a microscope, with the aid of a blepharostat, the positioning of the segments was performed according to the manufacturer nomograms and placement of therapeutic contact lenses.

\section{Postoperative medication}

The topical postoperative (postop) therapy was performed with 0,1\% dexametasone eye drop (Maxidex ${ }^{\circledR}$, Alcon Laboratórios do Brasil, São Paulo, Brazil) q.i.d. for 2 weeks; $0.3 \%$ gatifloxacin eye drop (Zymar ${ }^{\circledR}$, Allergan Laboratórios do Brasil, São Paulo, Brazil), q.i.d. for 1 week; hypromelosis associated with dextrane 70 (Fresh tears ${ }^{\circledR}$, Allergan Laboratórios do Brazil, São Paulo, Brazil) q.i.d. for 4 weeks, maintaining its use as required.

\section{Postoperative assessment}

Postoperative return visits were scheduled for the $1^{\text {st }}$ and $7^{\text {th }}$ days and $1^{\text {st }}, 2^{\text {nd }}$ and $3^{\text {rd }}$ months.

D 1:VA, biomicroscopy

D 7: VA, biomicroscopy; tonometry

D 30: VA, biomicroscopy, tonometry

D 60: VA, biomicroscopy, tonometry

D 90: VA, biomicroscopy, refraction, tonometry, Orbscan.

\section{OCULAR FINDINGS AND COMPLICATIONS}

During the postoperative assessments, all ocular findings with or without clinical significance and those which could mean a threatening to the visual function (complications), as well as the treatment used, when deemed necessary, were documented.

\section{Statistical analysis}

The data were presented as mean \pm standard deviation and proportions for continuous and categorical variables, respectively. Pre- and postoperative comparisons were performed with t-student and Wilcoxon paired tests. Vector analysis of the astigmatism was performed to detect its magnitude change and used procedure described by Jaffe, Clayman ${ }^{(11)}$. Comparisons between the groups (ectasia grade) were made with the Kruskall-Wallis test and multiple comparisons were corrected by the Bonferroni method. The statistical significance level was 0.05. Analyses were performed with Stata v.10 software (College Park, Texas, EUA).

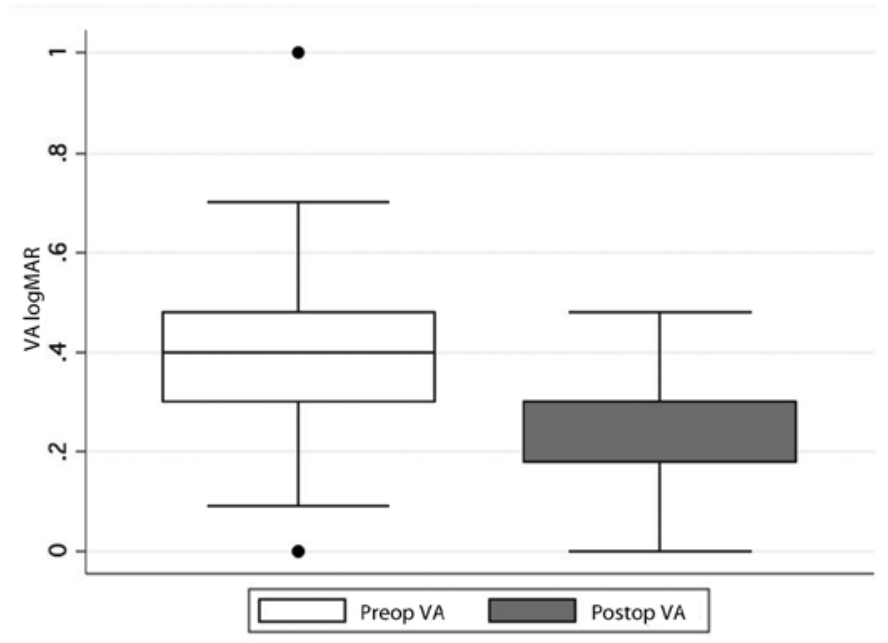

$\mathrm{VA}=$ visual acuity

t-student and Wilcoxon paired tests, $\mathrm{p}<0.05$

Figure 1. Visual acuity variation (logMAR) before and after the intrastromal ring implant in patients with corneal ectasia.

\section{RESULTS}

This study included 35 eyes of 35 patients. Twenty-two (62.8\%) male and 13 (37.2\%) female participated, with a mean-age of $29.6 \pm 8.9$ years. All patients completed a 3 month follow-up.

\section{TYPE AND STAGES OF ECTASIA}

Thirty-three (94.3\%) patients with keratoconus and 2 (5.7\%) patients with pellucid marginal degeneration participated in the study. Among keratoconic patients, 10 (30.3\%) were classified as grade I, 10 (30.3\%) as grade II, 8 (24.2\%) as grade III and 5 (15.2\%) as grade IV.

\section{Visual ACUITY}

Twenty-four patients (68.6\%) used spectacles, 10 (28.6\%) contact lenses and 1 (2.8\%) patient did not use any type of refraction correction.

There was a statistically significant improvement of the visual acuity in $82 \%$ of the patients on the third postoperative month. The corrected visual acuity improved from $0.4 \pm 0.20$ to $0.25 \pm 0.13$ (logMAR), $p=0.0002$ (Figure 1).

Among the patients with keratoconus, an improvement on visual acuity was noted in all groups, being statistically significant just in the grades II and III ( $p=0.015$ and 0.014 , respectively) (Table 1).

\section{SPHERICAL EQUIVALENT}

There was a statistically significant decrease $(p=0,0002)$ in the spherical equivalent (from $-5.41 \pm 4.78 \mathrm{D}$ to $-2.83 \pm 3.29 \mathrm{D}$ ) with the use of intrastromal ring (Table 2 ).

\section{TOPOGRAPHIC DATA}

A statistically significant reduction in the K-maximum (preop= $51.65 \pm 5.83 \mathrm{D}$, postop $=48.58 \pm 5.54 \mathrm{D}, \mathrm{p}=0.000)$ and in the $\mathrm{K}-\mathrm{mi}-$ nimum (preop $=45.92 \pm 4.64 \mathrm{D}$, postop $=43.96 \pm 5.06 \mathrm{D}, \mathrm{p}=0.0041)$ was noted (Table 2).

\section{Pachymetry}

Regarding the central pachymetry and the pachymetry in the thinnest point of the cornea, no statistical difference was noted. The central pachymetry varied from $473.94 \mu \mathrm{m} \pm 52.61 \mu \mathrm{m}$ in the preop to $479.77 \mu \mathrm{m} \pm 53.14 \mu \mathrm{m}$ in the postop, $(p=0.2236)$. Thinnest point measured ranged from $447.42 \mu \mathrm{m} \pm 52.47 \mu \mathrm{m}$ in the preop to $447.6 \mu \mathrm{m}$ $\pm 68.42 \mu \mathrm{m}$ in the postop, $\mathrm{p}=0.9848$.

\section{Anterior Chamber DePTH}

The depth variation of the anterior chamber was statistically significant, from $3.19 \mathrm{~mm} \pm 0.27 \mathrm{in}$ the preop to $3.16 \mathrm{~mm} \pm 0.28$ in the postop $(p=0.0480)$

\section{Posterior elevation}

Regarding the posterior elevation, it was noted a statistically significant reduction of it, from $54.54 \pm 4.19 \mathrm{D}$ in the preop to $53.37 \pm$ $3.32 \mathrm{D}$ in the postop $(\mathrm{p}=0.0016)$.

\section{Astigmatism Vector anAlysis}

The astigmatism change was performed through a vector analysis. The change magnitude of the astigmatism with the intracorneal ring implant for the study population was: mean of $3.92 \pm 2.52 \mathrm{D}$; median of $2.92 \mathrm{D}$ e range of 0.98 - 10.91 diopters. There was no significant difference among the several grades of ectasia (Table 3).

\section{Complications}

There were no surgical complications in this study. Only one patient needed to exchange the intrastromal ring of $5 \mathrm{~mm}$ by one of $6 \mathrm{~mm}$ due to halos observation. 


\section{DISCUSSION}

Studies regarding the use of intrastromal ring in the keratoconus treatment have been very frequent in the last years. This technique is becoming a more attractive solution to patients whose the alternative was the corneal transplant. Among the main advantages of this surgery, we highlight the corneal positive aspheric preservation, the lack of surgical scaring in its central portion and its reversible characteristic. In the event of an unexpected result, penetrating keratoplasty has been described with good outcomes. Besides, there is no problem in performing the corneal transplant in case the ring surgery does not achieve the expected result ${ }^{(12-14)}$.

A statistically significant reduction of the spherical equivalent was noted in our sample leading to improvement of the visual acuity in $82 \%$ of the patients after the ring implant, which was also found in other studies ${ }^{(2,7,8,15-17)}$, showing the efficacy of the method to correct corneal ectasias, previously corrected only with transplant. This improvement was statistically significant in groups which had keratoconus grade II, III and in both cases of pellucid marginal degeneration. Alió et al., (2005) had also shown better results in these keratoconus groups $^{(18)}$. In our study, only 3 eyes showed a worsening of 1 line of vision and in 3 eyes maintained the visual acuity, as reported by Alió et al., (2005) with 5 patients and Boxer et al., (2003) with 2 patiens ${ }^{(18,19)}$.

In the present study, a significant reduction in the topographic data as maximum K and minimum K was also noted. Previous studies showed a corneal flattening of approximately 4 diopters, very close to the one found in this study, which was 4.6 diopters ${ }^{(2,6,8,16)}$. In gene-

Table 1. Variation of the visual acuity (logMAR) before and after the intrastromal ring implant, according to the keratoconus grade

\begin{tabular}{lccc}
\hline Ectasia grade & Pre VA logMAR & Post VA logMAR & p value \\
\hline I & $0.26 \pm 0.04$ & $0.19 \pm 0.04$ & 0.268 \\
II & $0.39 \pm 0.06$ & $0.20 \pm 0.03$ & 0.015 \\
III & $0.46 \pm 0.02$ & $0.27 \pm 0.05$ & 0.014 \\
IV & $0.61 \pm 0.10$ & $0.39 \pm 0.03$ & 0.179 \\
\hline VA= visual acuity & & \\
t-Student and Wilcoxon paired tests, $p<0.05$ & &
\end{tabular}

Table 2. Variation of the spherical equivalent and keratometry before and after the intrastromal ring implant in patients with corneal ectasia

\begin{tabular}{lccc}
\hline & Preoperative (D) & Postoperative (D) & p \\
\hline SE & $-5.41 \pm 4.78$ & $2.83 \pm 3.29$ & 0.0002 \\
K-maximum & $51.65 \pm 5.83$ & $48.58 \pm 5.54$ & 0.0000 \\
K-minimum & $45.92 \pm 4.64$ & $43.96 \pm 5.06$ & 0.0041 \\
\hline
\end{tabular}

$\mathrm{SE}=$ spherical equivalent; $\mathrm{D}=$ diopters; $\mathrm{K}=$ keratometry

t-Student and Wilcoxon paired tests, $\mathrm{p}<0.05$

Table 3. Astigmatism vector analysis with the intrastromal ring in patients with corneal ectasia

\begin{tabular}{lcccc}
\hline & Grade I & Grade II & Grade III & Grade IV \\
\hline Astigmatism, mean $\pm \mathrm{dp}$ & $5.59 \pm 3.85$ & $2.99 \pm 1.32$ & $3.12 \pm 1.56$ & $3.61 \pm 1.12$ \\
Median (range) & $5.38(1.65-10.91)$ & $3.05(0.98-5.50)$ & $2.83(1.81-6.78)$ & $3.83(2.12-5.04)$ \\
\hline
\end{tabular}

Kruskall-Wallis test, Bonferroni method



Preoperative

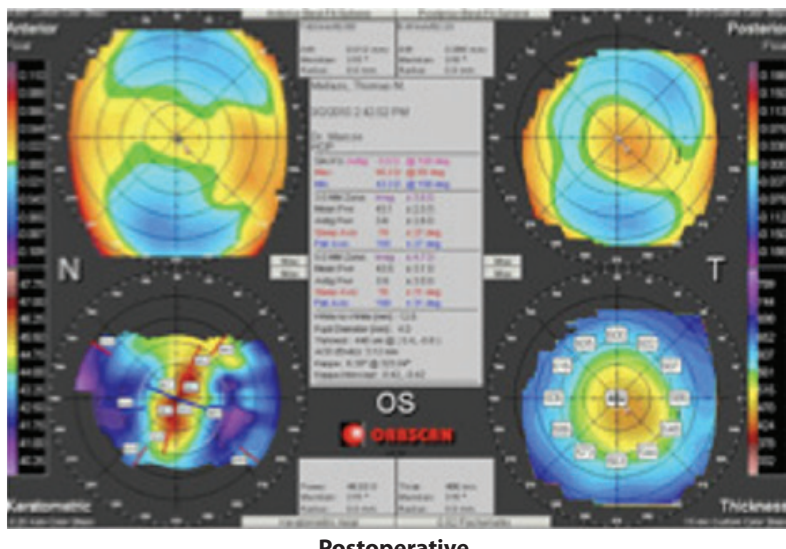

Postoperative

Figure 2. Patient submitted to ICRS implant. There was an improvement in the maximum K of 5.6 D (preop=51.9 D and postop=46.3 D), and, consequently, in the spherical equivalent which reduced from $-3.25 \mathrm{D}$ to $-0.50 \mathrm{D}$ and the visual acuity which was from 0.48 to 0.09 (logMAR), besides the increasing in the corneal thickness (preop $=441 \mu \mathrm{m}$, postop $=445 \mu \mathrm{m}$ ). 
ral, it occurs due to an important corneal flattening in the first days after the implant and the measures become stable approximately 3 months postoperatively ${ }^{(1)}$ (Figure 2).

The mechanism of ICRS is the addition of material in the corneal periphery, an arc-shortening effect on the corneal lamelae, flattening the central cornea. For the correction of astigmatism the end point of each segment may produce additional tening ${ }^{(20)}$. With the corneal flattening after the surgical procedure, patients can experience an important reduction of the corneal irregularity and astigmatism, making possible the use of soft contact lenses with a good visual acuity and satisfactory fitting ${ }^{(6)}$. In this study, the astigmatism vector analysis showed a mean improvement of $3.92 \pm 2.52$ diopters.

During the study, no intraoperative complications such as corneal perforation or incomplete tunnel formation were noted. No postoperative complications such as migration of the segments, as already reported ${ }^{(3,21)}$, were noted. It is probably due to the use of the femtosecond laser to create the stromal tunnel. Its use makes the procedure safer (more uniform tunnel depth), faster and more comfortable to the patient and to the surgeon ${ }^{(7-9,22,23)}$, although the results regarding visual acuity are similar to the ones found when the manual technique is performed by experienced surgeons $s^{(8,2,24)}$. One patient needed to exchange the intrastromal ring of $5 \mathrm{~mm}$ by one of $6 \mathrm{~mm}$ due to halos observation.

\section{CONCLUSION}

The results of this study showed that the intrastromal ring implant Keraring ${ }^{\circledR}$ with femtosecond laser is a safe procedure, with low risk of complications, determining important improvement on visual acuity and topographic data of patients with corneal ectasia.

\section{REFERENCES}

1. Oliveira CS, Moreira H, Wahab SW, Godoy G. Análise de nova técnica para o implante do anel de Ferrara no ceratocone. Arq Bras Oftalmol. 2004;67(3):509-17.

2. Kubaloglu A, Sari ES, Cinar Y, Cingu K, Koytak A, Coșkun E, et al. Comparison of mechanical and femtosecond laser tunnel creation for intrastromal corneal ring segment implant in keratoconus: prospective randomized clinical trial. J Cataract Refract Surg. 2010;36(9):1556-61.

3. Ertan A, Bahadir M. Intraestromal ring segment insertion using a femtosecond laser to correct pellucid marginal corneal degeneration. J Cataract Refract Surg. 2006;32(10): 1710-6.

4. Belin MW, Fowler C, Chambers WA. Evaluation of recent trends in the surgical and non surgical correction of keratoconus. Ophthalmology. 1988;95(3):335-9.
5. Dana MR, Putz JL, Viana MA, Sugar J, McMahon TT. Contact lens failure in keratoconus management. Ophthalmology. 1992;99:1187-92. Comment in: Ophthalmology. 1992;99(12):1752-3; Ophthalmology. 1993;100(2):147-8

6. Cunha PF, Alves EA, Silva FB, Cunha GH. Estudo das modificações oculares induzidas pelo implante estromal do anel de Ferrara em portadores de ceratocone. Arq Bras Oftalmol. 2003:66(4):417-22.

7. Shabayek MH, Alio JL. Intrastromal corneal ring segment implant by femtosecond laser for keratoconus correction. Ophthalmology. 2007;114(9):1643-52.

8. Coskunseven E, Kymionis GD, Tsiklis NS, Atun S, Arslan E, Jankov MR, et al. One-year results of intrastromal corneal ring segment $n$ implantation (KeraRing) using femtosecond laser in patients with keratoconus. Am J Ophthalmol. 2008;145(5):775-9.

9. Carrasquillo K, Rand J, Tálamo JH. Intacts for keratoconus and post-LASIK ectasia: mechanical versus femtosecond laser-assisted channel creation. Córnea. 2007;26(8): 956-62.

10. Krumeich JH, Daniel J, Knülle A. Live-epikeratophakia for keratoconus. J Cataract Refract Surg. 1998:24(4):456-63.

11. Jaffe NS, Clayman HM. The pathophysiology of corneal astigmatism after cataract extraction. Trans Am Acad Ophthalmol Otolaryngol. 1975:79:615-30.

12. Holmes-Higgin DK, Baker PC, Burris TE, Sivestrini TA. Characterization of the aspheric corneal surface with intrastromal corneal ring segments. J Refract Surg. 1999;15(5): 520-8.

13. Nosé W, Ferrara P. Anillo intracorneal. In: Albertazzi R, Centurion V. La moderna cirurgia refrativa. Buenos Aires: Gustavo Multedo; 1999. p.167-81.

14. Moreira H, Oliveira CS, Godoy G, Wahab SA. Anel intracorneano de Ferrara em ceratocone. Arq Bras Oftalmol. 2002:65(1):59-63.

15. Ertan A, Kamburoglu G, Bahadir M. Intacts inserction with the femtosecond laser for the management of keratoconus: one year results. J Cataract Refract Surg. 2006; 32(12):2039-42

16. Colin J, Cochener B, Savary G, Malet F, Holmes-Higgin D. INTACS inserts for treating keratoconus: one-year results. Ophthalmology. 2001;108(8):1409-14.

17. Silva DSM. Avaliações clínica e cirúrgica dos segmentos do anel intra-estromal de Ferrara R em pacientes portadores de ceratocone (Tese). São Paulo: Universidade Federal de São Paulo; 2004

18. Alió JL, Shabayek MH, Belda Jl, Correas P, Felioo ED. Analysis of results related to good and bad outcome of Intacts implant for correction of keratoconus. J Cataract Refract Surg. 2006;32(5):756-61.

19. Boxer Walcher BS, Christie JP, Chandra NS, Chou B, Korn T, Nepomuceno R. Intacts for keratoconus. Ophthalmology. 2003;110(5):1031-40. Erratum in: Ophthalmology. 2003;110(8):1475

20. Renesto AC, Campos M. Intrastromal corneal ring segments. In: Krachmer JH, Mannis MJ, Holland EJ, editors. Cornea. Philadelphia: Elsevier Mosby; 2011. p.1893-8.

21. Hofling-Lima AL, Branco BC, Romano AC, Campos MQ, Moreira H, Miranda D, et al. Corneal infections after implantation of intracorneal ring segments. Cornea. 2004; 23(6):547-9.

22. Ratkay- Traub I, Ferincz IE, Juhasz T, Kurtz RM, Krueger RR. First clinical results with the femtosecond neodymium-glass laser in refractive surgery. J Refract Surg. 19(2):94-103.

23. Carrasquilho OD, Rand J, Talamo JH. Intacts for keratoconus and post-LASIK ectasia: mechanical versus femtosecond laser-assited channel creation. Cornea. 2007; 26:(8):956-62

24. Alio JL, Artola A, Hassanein A, Haroun H, Galal A. One or two Intacts segments for the correction of keratoconus. J Cataract Refract Surg. 2005;31(5):943-53.

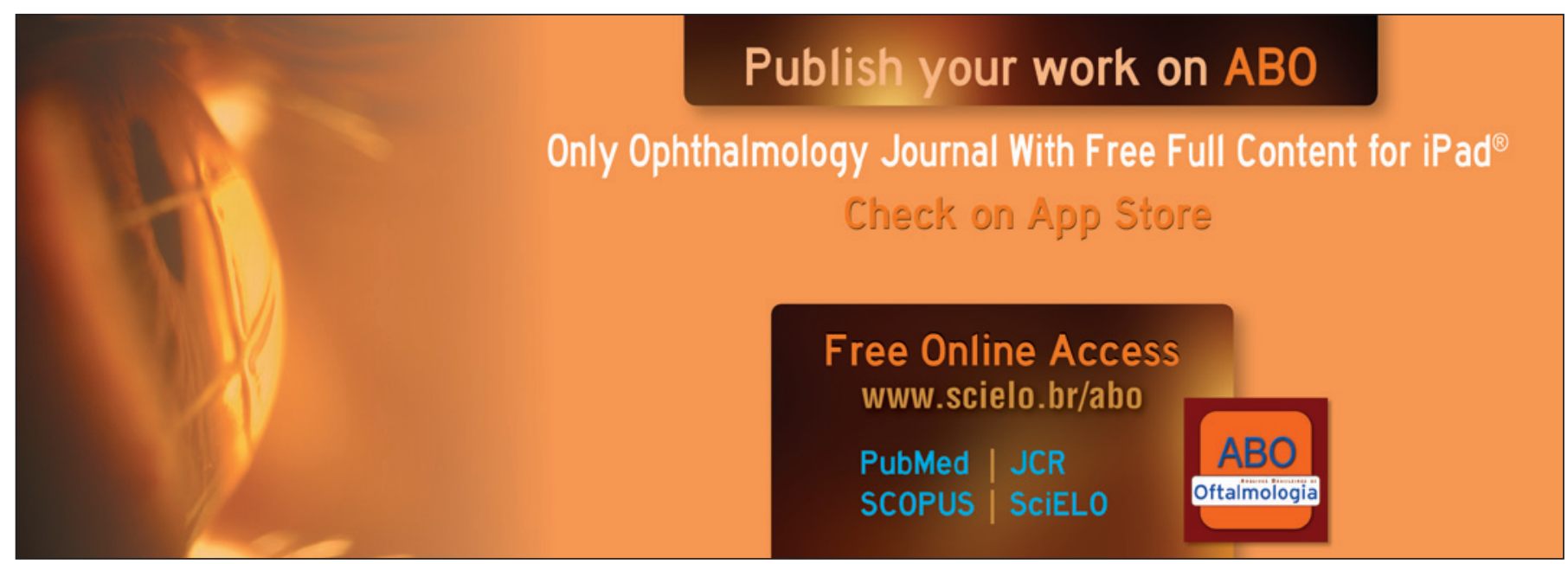

